Case Reports

Arch. Esp. Urol. 2009; 62 (7): 599-602

\title{
RHABDOMYOSARCOMA METASTATIC PARATESTICULAR
}

Oscar Heredero Zorzo, Maria Fernanda Lorenzo Gomez, Juan Miguel Silva Abuin, Pablo Eguiluz Lumbreras, Patricia Antunez Plaza', Angel Gil Vicente, Agustin Martin Rodriguez and Manuel Urrutia Avisrror.

Departments of Urology and Pathology'. Salamanca Universitary Clinic Hospital. Salamanca. Spain.

Summary.- OBJECTIVES: To report one case of metastatic paratesticular rhabdomyosarcoma in a 14 years old patient, classified as stage IIb (IRSG).

METHODS: After treatment with radical surgery /orchiectomy and lymphadenectomyl, polychemotherapy and radiotherapy, showed good evolution initially.

RESULTS: 12 months after surgery the patient is disease free.

CONCLUSIONS: Adjuvant treatment is very important in the prognosis of this kind of tumors.

Oscar Heredero Zorzo

Obispo Barbado Viejo, 17 - 3-A.

3700 1. Salamanca. (Spain)

oscarheredero@hotmail.com

Accepted for publication: February 23th, 2009. 
Keywords: Rhabdomyosarcoma. Paratesticular tumor.

Resumen.- OBJETIVOS: Presentar un caso de rabdomiosarcoma paratesticular metastásico en un varón de 14 años de edad, clasificado como estadio Ilb según el IRSG (Intergroup Rhabdomyosarcoma Study Group).

MÉTODOS: Tras recibir tratamiento mediante cirugía radical (orquiectomía más linfadenectomía retroperitoneal), poliquimioterapia y radioterapia, presentó buena respuesta inicialmente.

RESULTADOS: A los 12 meses de la intervención quirúrgica el paciente se encuentra libre de enfermedad.

CONCLUSIONES: Resultan fundamentales la quimioterapia y/o radioterapia adyuvantes para el tratamiento de estas neoplasias.

Palabras clave: Tumor paratesticular. Rabdomiosarcoma.

\section{INTRODUCTION}

Most of the paratesticular tumors, such as adenomatoid tumors and lipomas, are benign (70\%). Malignant tumors represent around $30 \%$ of the total, and they are mainly sarcomas.

Rhabdomyosarcomas are the most common soft tissue sarcomas during childhood $15 \%$ of all the pediatric neoplasias), but only $7 \%$ of them are presented in a paratesticular location (1-3).

Although these tumors are usually found in their initial stages, sometimes they are locally developed or they present distance metastasis at diagnosis.

We present the case of a paratesticular rhabdomyosarcoma with affected retroperitoneal lymph nodes, with a good initial response after a combined treatment (radical surgery, polychemotherapy, retroperitoneal lymphadenectomy and radiotherapy).

\section{CASE REPORT}

Male patient of 14 years of age, with no relevant personal record. The patient is admitted as an emergency with an increased right hemiscrotum of 1 month of evolution, and he also reports pain in the right lumbar area. He has no record of cryptorchidism or other scrotal traumas. The examination reveals a tumor in the rig- ht hemiscrotum of approximately $10 \mathrm{~cm}$, surrounding the testis, with negative transillumination. No inguinal adenopathies were observed.

An emergency ultrasound is required, in which a right scrotal heterogeneous tumor of $9 \mathrm{~cm}$ with vascular flow is found. The tumor displaces the healthy testicular parenchyma. The testicular markers ( $\alpha$-fetoprotein and $\beta-H C G)$ are normal, and LDH levels are in the limit of normality.

A radical right radical inguinal orchiectomy is performed. The anatomo-pathological analysis shows a poorly differentiated (primitive) embryonic rhabdomyosarcoma, with wide areas of fusocellular differentiation and tumor necrosis (Figure 1), with a paratesticular origin and $12 \mathrm{~cm}$ of maximum diameter. Tumor immunophenotype: Vimentin and Desmin (+), Actin (+) focal, S100 (+) focal and CD56 (+) diffuse. There was infiltration in the epididymis, the tunica albuginea and the tunica vaginalis, without evidence of infiltration of the spermatic cord.

The abdominopelvic staging CT reveals millimetric nodes in both lower lobes adjacent to the major fissure, with subcentrimetic mesenteric adenopathies, left paraaortic adenopathies of non-significant size, and also in the primitive right iliac chain, of $2 \times 1.5 \mathrm{~cm}$. The bone scan was negative. Three whole cycles of treatment with VAC (Vincristine, Dactinomycin and Cyclophosphamide) were applied.

After the chemotherapy cycles, a control CT was performed prior to the beginning of the treatment with ra-

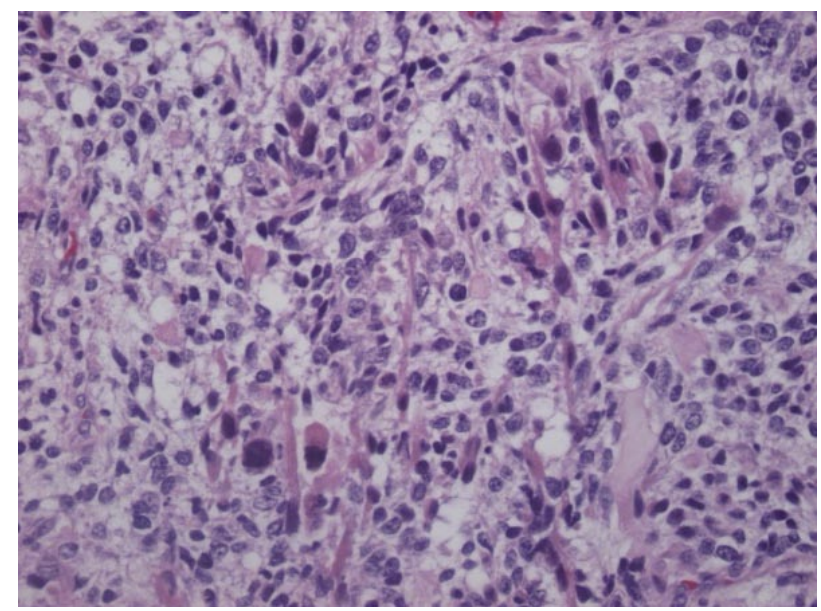

FIGURE 1. Neoplasia of high cellular density constituted by elements poorly separated from aspect sarcomatoide and attends of rabdomioblastos. 


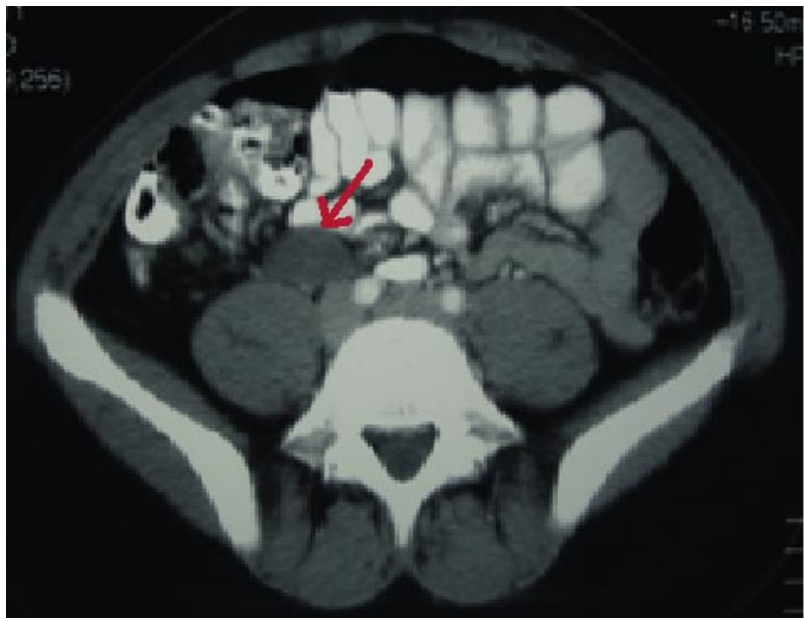

FIGURE 2. Paracaval adenopathy of $3.5 \mathrm{~cm}$.

diotherapy, which revealed a progression in the size of the retroperitoneal adenopathies (in the primitive right iliac chain, of $3.5 \mathrm{~cm}$, and in the interaortocaval area, of $1.5 \mathrm{~cm}$ ) (Figure 2). A retroperitoneal paracaval and interaortocaval lymphadenectomy is performed, extended to the iliac areas (Figure 3). The anatomo-pathological analysis reveals metastatic nodes of embryonic rhabdomyosarcoma. The patient is classified as a stage Ilb of the C6 classification of the IRSG (Table I) 4 or stage II of TNM (T2N1MO).

After surgery, new cycles of chemotherapy (Iphosphamide, Vincristine, Actinomycin D and Doxorubicin), followed by concomitant treatment of chemotherapy and radiotherapy were applied.

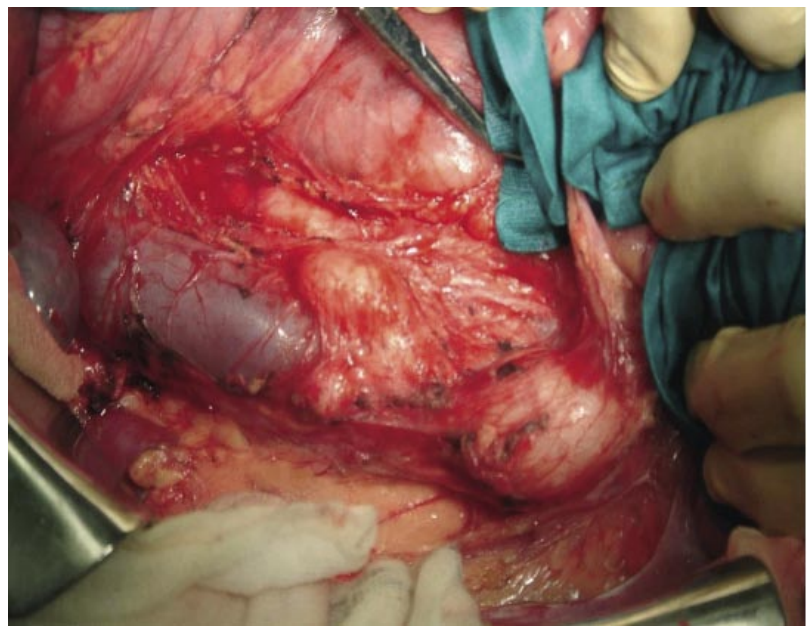

FIGURE 3. Extirpation of retroperitoneal residual masses after chemotherapy.
Twelve months later, the patient is disease free. Two months later he reports acute pain in the left costal area. A new thoraco-abdomino-pelvic CT reveals several small bone metastases in the ribs, vertebrae, pelvis and femur, and also small hepatic and lung metastases. The patient is still hospitalized with analgesic treatment and chemotherapy

\section{DISCUSSION}

Paratesticular rhabdomyosarcoma is an uncommon neoplasia, with an incidence of around 4 to 7 cases per year per million of males. It appears mainly during the first two decades of life, and it is exceptional in adults. The paratesticular tissues from which it develops may be the epididymis, the spermatic cord, the testicle membranes and the connective tissue of the scrotum (2). Histologically, there are three types of paratesticular rhabdomyosarcomas: pleomorphic, embryonic and alveolar; and the embryonic type is the most common in the paratesticular region (3).

Generally, the patients report an increase of the scrotal size, which can involve the testis, as in our case, or else appear as a paratesticular mass. It does not cause pain, and it increases progressively in size.

Ultrasounds are the test of choice for the study of the intrascrotal masses. They can reveal the solid character of the mass, and they can show whether the lesion affects the testis or it is an extratesticular lesion (5). An extension study must be performed, with abdomino-pelvic $C T$, thoracic $R x$ and bone scan.

When the diagnostic suspicion has been established, the initial treatment is an inguinal orchiectomy with high and early clamping of the spermatic cord. Depending on the staging of the Intergroup Rhabdomyosarcoma Study Group (IRSG), different lines of action are recommended. Adjuvant chemotherapy is recommended in Stage I, and further stages (Table I) also require retroperitoneal lymphadenectomy, chemotherapy (according to different patterns) and radiotherapy (3). The most controversial point evolves around the most adequate treatment for these stages: although retroperitoneal lymphadenectomy is recommended in cases in which there is suspicion of nodular affectation in the image tests, this is a contested point, as other authors propose this surgical option in the case of retroperitoneal residual masses after chemotherapy $(6,7)$.

With the appearance of the new chemotherapy drugs and their combined use with radical surgery, survival rates have increased greatly in this type of tumors, reaching general levels of $95 \%$ at the first three years and $92 \%$ at five years $(3,8)$. Early diagnosis and surgery are essential for the prognosis. In any case, we must remember that these tumors present a high biological aggressiveness and that an aggressive treatment 
TABLE I. STAGING OF RHABDOMYOSARCOMAS ACCORDING TO THE IRSG.

\begin{tabular}{|l|c|}
\hline GRUPO & DEFINITION \\
\hline STAGE I & $\begin{array}{r}\text { Localized and completely resected tumor. } \\
\text { a: located in the original muscle or organ and completely resected } \\
\text { b: infiltrated out of the original location }\end{array}$ \\
\hline STAGE II & $\begin{array}{c}\text { Completely resected but with evidence of local dissemination. } \\
\text { a: complete macroscopic resection with residual microscopic disease } \\
\end{array}$ \\
& b: local nodes affected but completely resected \\
& c: both a and b \\
\hline STAGE III & Localized and incompletely resected tumor, or exclusively biopsied tumor \\
\hline STAGE IV & Disease with metastasis at diagnosis \\
\hline
\end{tabular}

does not necessarily imply the control of the disease, as is the case with our patient.

\section{REFERENCES AND RECOMENDED READINGS (*of special interest, ${ }^{* *}$ of outstanding interest)}

1. Quesada E M, Díez B, Silva M, Muriel F S, Chemes H. Paratesticular rhabdomyosarcoma in children. $\mathbf{J}$ Urol, 1984; 136: 303-304.

*2. Mora Nadal J I, Ponce Campuzano A, Llopis Manzanera J, Miró Queralt J. Rabdomiosarcoma paratesticular. Actas Urol Esp, 2004; 28 (2): 245-248.

**3. Andréu García A, Herrero Polo E, Alapont Alacreu J M, Botella Almodóvar R, Schiefenbusch Munné E, Brotons Márquez J L, García Arranz P, Llamazares Cachá G. Rabdomiosarcoma Paratesticular: A propósito de un caso. Arch Esp Urol, 2005; 58 (2): 161-163.
4. Raney R B, Maurer H M, Anderson J R, Andrassy $\mathrm{R} J$, Donaldson S S, Qualman S J, et al. The Intergroup Rhabdomyosarcoma Study Group (IRSG): Major lessons from the Irs-I through Irs-Iv studies as background for the current Irs- $\mathrm{V}$ treatment protocols. Sarcoma, 2001; 5: 9-15.

5. Mak C W, Chou C K, Su C C, Huan S K, Chang J M. Ultrasound diagnosis of paratesticular rhabdomyosarcoma. Br J Radiol, 2004; 77: 250-252.

6. Goldfarb B, Khoury A E, Greenberg M L, Churchill B M, Smith C R, McLoire G A. The role of retroperitoneal lymphadenectomy in localized paratesticular rhabdomyosarcoma. J Urol, 1994; 152: 785-787.

7. Castillo O, Kerkebe M, Pinto L, Santomil F, García J L, Arellano L. Linfadenectomía lumboaórtica laparoscópica post-quimioterapia. Revista Chilena de Urología, 2002; 67 (2): 115-118.

8. Méndez Gallart R, Gómez Tellado M, Montero Sánchez M, Arnaiz Peña S, Vela Nieto D, País Piñeiro E. Rabdomiosarcoma paratesticular. Actas Urol Esp, 1999; 23: 549. 